\title{
Exploration of the Actual Combat Teaching in Noncommissioned Officer Academies in-depth Development
}

\author{
Xiangjun XU, Zelong ZHOU, Huilai FAN, Rongyue XIE \\ Wuhan Mechanical College, Hubei, China
}

\begin{abstract}
Practical teaching is refers in the approximate actual combat environment and conditions of education and training activities, is comprehensively implement the training principle of "training war training agreement", the teaching and training of environmental conditions through the creation of highly close combat degree, strictly conform to the actual requirements of the teaching content and teaching training standard, flexible use of various methods of training "methods close to actual combat, combat, similar to simulated combat, in line with the actual", in order to maximize shorten the gap between training and operation, improve the college students to carry out future combat mission of combat capability for the objective of military practice. The in-depth development of practical teaching is a requirement under the new situation the army colleges and universities mission development, scientific advance practical teaching is an important sign of the deepening development of college military training. Facing the new situation, how to carry out in depth the petty officer academy of actual teaching, personnel training can effectively perform equipment repair support mission in the future battlefield is a major practical problem in front of us.
\end{abstract}

KEYWORD: NCO; Actual; Combat

\section{THE NECESSITY TO CARRY OUT IN-DEPTH PRACTICAL TEACHING, A SERGEANT COLLEGE}

The sergeant education is a kind of military occupation education, cultivate cadet is practical and the goal of clear direction, improve the teaching contents, teaching organization, teaching management level of the combat, enhance the quality of training personnel of the rigid demand is under the new situation, but also an important means of personnel full foot team post ability demand is the fundamental guarantee for the future war, our army victory[1].

\subsection{To carry out the actual combat teaching and} Training Officer College is the rigid demand of enhancing the quality of personnel training in the new situation

Practical teaching is the implementation of college education to move closer to the concrete embodiment of troops. Practical teaching is to combat missions, in order to combat environment as the background, in order to improve the combat effectiveness of teaching activities and teaching methods of fundamental and close to the war. The current college teaching and the requirements of the army still exists a certain gap, realize the teaching and training of troops seamless docking, to enhance the quality of talent cultivation is the fundamental task of sergeants in actual combat teaching.

Strengthen the sergeant position task in the teaching link of traction, on the basis of job tasks, design of teaching goal, according to the teaching objectives, planning teaching reform. Through the actual teaching, the design of equipment support in battle, exercise equipment in repair, learn to fight war battlefield repair, enhance forward-looking, scientific and effectiveness of teaching, persist in reform and innovation, strengthen the consciousness of problems forced, for the short board and the weak links of innovation of college teaching contents, teaching organization and teaching management protection equipment repair, and personnel training to improve the quality, good talent and fighting capacity reserve for future war.

\subsection{To carry out the actual combat teaching and Training Officer College is important means to meet the army post personnel capacity requirements}

With the development of weapons and equipment 
renewal speed continues to accelerate, weapon system integration more and more high, force protection equipment repair job setting constant changes, the corresponding functions are also constantly changes expand, so the army post on personnel's ability to put forward new and higher demand. To carry out the actual combat teaching and training officer to army post on colleges, personnel ability demand as the starting point, follow the principles personnel ability, through long-term training to personnel for specific jobs can achieve change from quantity accumulation to qualitative, and ultimately the formation of meet the guarantee ability of actual combat conditions, specific equipment repair job, reach "graduation to posts" state[2-3].

\subsection{Sergeant colleges to carry out the actual combat teaching and training is the fundamental guarantee for the future of our military victory in the war}

Cadet officer cadets with respect to closer to the battlefield, operation and use are mostly engaged in equipment repair, security and other infrastructure work, in the future war cadet will play an irreplaceable role. Is to be cruel and real war goes forward to carry out the actual combat teaching petty officer academy, transplanted to the training stage Cadet NCO cadets in advance, so that through the actual combat training accepted war "baptism", to adapt to the environment, and in practical teaching of "embedded" battlefield, exercise skills. A large number of actual combat training after personnel officer college, will be to enrich the post, security forces a line equipment is ready for the future war, our army's victory to provide a solid foundation.

\section{SERGEANT COLLEGES SHOULD FOCUS ON GRASPING THE IN-DEPTH DEVELOPMENT OF ACTUAL COMBAT TEACHING}

\subsection{Insist on demand traction}

At present the army equipment development change rapidly, equipment support form from a single original form gradually to the direction of the development of integrated equipment support, the conventional operation using tectonic principle Repair - decomposition combined detection model in a certain period of time to enhance the Cadet equipment repair ability, but for battlefield repair, with security oriented battlefield practical training subjects carried out is still a lack of implementation mechanism, which makes the NCO cadets in the colleges and universities learning knowledge, acquire skills can not be timely into the battlefield needs fighting capacity. The sergeant education post adaptability and point to the requirements of its must be oriented to the future battlefield is actual, to move closer to meet war battlefield, demand as the fundamental purpose, focus on the future battlefield, analysis of cadet mission, according to task to determine post ability demand, on the basis of post ability demand to determine the training objectives, training content, training based on goal programming method management and security, and other content.

\subsection{Adhere to the practice ability training}

The future war is the war officer. Personnel officer college directly facing the war, relative officers, from the more recent war, Sergeant education goal is to direct for war service, personnel cultivating a large number of high-quality have excellent equipment support technology, in essence is the sergeant education is a kind of military occupation education, so we must pay more attention to the Cadet job skills training, emphasizing the theory to the application of knowledge to ability, transformation, the come down in one continuous line and close to the actual combat requirements. But, at present as part of the NCO academies reasons in many aspects by the teaching thought college degree education effect, in the design of training programs and the content to some extent by the education mode of training effect, the heavy theory, light practice heavy system, lack of training, clear positioning needs to army personnel, teaching content "air to air", research on the problem of the lack of targeted, specific requirements from Cadet post office on knowledge, ability, quality of the. In the process of actual teaching implementation, must pay attention to practice teaching, practical, close to the equipment to carry out teaching, field teaching, combined with teaching, adopt United Education joint training, post practice teaching mode, establish a noncommissioned officer post all-round, threedimensional, real need practical teaching system.

\subsection{Adhere to the position of comprehensive ability}

Equipment maintenance and support force in the future battlefield into has broken through the boundaries of professions and trades, technology integration more and more high master equipment, personnel single professional professional skills has been unable to meet the requirements of actual maintenance task environment. Put forward higher requirements to ensure the task of development and transformation of battlefield equipment equipment ability of the personnel and equipment protection. So the petty officer academy of actual teaching must adhere to the principle of comprehensive ability, accurately grasp the equipment repair support post ability demand, the decomposition capacity requirements in actual combat teaching, refined to 
specific training courses, through long-term training, the Cadet master actual combat conditions specific job skills, gradually cultivating comprehensive ability of cadet equipment repair support, to meet the needs of for equipment repair support tasks in future battlefield.

\section{APPROACHES AND METHODS TO CARRY OUT AN IN-DEPTH PRACTICAL TEACHING IN THREE, SERGEANT COLLEGE}

\subsection{The personnel training plan for the top-level design requirements of the Army Science}

Accurately grasp the actual requirements for working ability noncommissioned officer position, facing the army needs scientific planning personnel training top design is a prerequisite to carry out practical teaching. First of all to develop scientific programme design talent, to the real battlefield environment on petty officer post qualities and ability as the main basis, making the training target and plan of professional talents, and strive to achieve the "have a definite object in view" training personnel. Two is to optimize the course system, teaching content to form a "convergence based application ability - war" knowledge system, features of the system of combat teaching outstanding under the condition of information, enhance the teaching pertinence and practice. Three is the scientific formulation of curriculum standard, to "systematic working process" as the theoretical basis, to the battlefield environment specific tasks for the traction force, reference workflow enactment curriculum standards and curriculum implementation plan, the creation of actual teaching situation, and strive to achieve consistent training, teaching and the battle line.

\subsection{Close to the actual combat equipment construction of teaching content system}

What equipment combat, focus on learning what equipment, what to focus on learning what troops need. During the cadet school equipment operation maintenance learning, skills, must be facing the actual combat equipment to carry out the study. According to the actual combat equipment configuration model, carry out the equipment learning, in strict accordance with the real conditions of equipment integrated logistic support process to carry out training, in order to combat missions set training subjects, training form of specification. Scientific planning and equipment of learning content, to achieve the "three simultaneous", the teaching and training of equipment model and actual combat training synchronization, equipment training subjects and actual combat training synchronization, equipment training environment and actual combat training synchronization. Synchronization by maintaining and actual combat training, NCO cadets in training process in strict accordance with the army post demand "tailored", which makes the Cadet graduation to posts, posts that can fight effectively make, petty officer academy equipment training aimed at actual combat troops, meet the job requirements, achieve the training according to the actual combat standard implementation at ordinary times, the actual operation such as the usual training effect of execution, ensure "like a battle training".

The actual equipment prone diagnosis, multiple troubleshooting method as a key study content. Equipment failure mechanism under the condition of actual combat is susceptible to environmental impact, to a comprehensive analysis of various factors influencing the combat equipment, a comprehensive grasp of the performance, timely detection and elimination of equipment are prone to failure. Equipment $\mathrm{NCO}$ cadets functions in the future battlefield is to complete a comprehensive security battlefield equipment, security equipment performance intact, promptly eliminate equipment failure. Therefore, Sergeant college close to actual combat equipment construction of teaching content system must be combat equipment prone diagnosis, multiple troubleshooting method as a key study content. According to the equipment fault mechanism of actual combat, be arranged to summarize, sum up the actual condition of equipment are prone to failure, the formation of the actual combat equipment fault case set, specification of actual conditions of flow under battlefield repair, have a definite object in view to develop the Cadet combat equipment repair support training, improve practical teaching content target.

Teaching content will be formed to combat equipment fault repair ability as the key and difficult teaching points. Fault repair ability of actual combat equipment is the comprehensive ability of $\mathrm{NCO}$ cadets through college education and training culture. Cadet in addition to the acquisition of equipment repair skills through the study of equipment operation, construction principle, detection and repair and other professional courses, but also must learn the use of metal technology, material science, electronic engineering and other basic courses under the condition of knowledge processing actual battlefield damaged equipment repair. The teaching content of fault repair ability of actual combat equipment must be reasonable planning, effective connection of basic courses and professional courses, according to the actual combat training requirements, carding equipment fault detection and repair related subjects, reasonable formulation of the basic knowledge and professional knowledge depth and breadth, aimed at improving teaching content system. 


\subsection{Close to the actual combat post innovation teaching training mode}

Follow the "how to make a fight, to carry out the teaching and training soldiers how to practice the principle of". Practical teaching must be based on combat missions, in order to combat environment as the background, to improve the combat effectiveness of fundamental practical training. The future war situation changes rapidly, if we want to win the war in the future, the initiative must grasp of the battlefield, to carry out practical teaching war mode. Follow the combat training traction law, as far as possible understanding of the future war features, rules and requirements, what the war needs, repeatedly practice what, what is most useful in actual combat, put what practicing sperm, ensure the correct direction of military training. Through careful study of previous examples of the characteristics, laws and changes to "stones from other hills may attack the jade" attitude to sum up experience and lessons, as understanding and formulate the actual combat training content, standard basis, and constantly enhance the teaching pertinence. "The battle and who fight, soldiers will be staring at the who practice", aim at the enemy, make teaching more targeted, the synchronous development of colleges and universities teaching training and the form of war.

According to the actual equipment position design teaching task and situation. Equipment officer will play a more and more important role in the future battlefield equipment integrated support link, the different positions of the officer will be responsible for different tasks, according to the actual combat equipment design and development of post teaching task scene equipment teaching will clear the Cadet equipment learning content, so that colleges and universities teaching content and actual combat equipment post ability demand docking. The task of teaching settings configuration equipment according to the operation personnel requirements, the teaching scene completely simulated combat environment, the $\mathrm{NCO}$ cadets in the teaching process of "embedded" combat environment, master the corresponding post repair guarantee process. In the design of teaching contents, the actual equipment post ability demand form the "mapping" and teaching tasks and situations, composed of correspondence, one by one in the process of teaching break, make the Cadet professional skills quickly upgrade.

According to the actual equipment repair process organization training teaching. Equipment repair support has important significance for future combat battlefield play equipment. Rational planning of teaching content system in the practical teaching link, based on the actual combat environment standard combat equipment maintenance process, formulate detailed battlefield repair procedures, and strengthening the training can enhance the professional skills of NCO cadets in real conditions, to meet the actual combat environment maintenance requirements.

In accordance with the actual requirement of the construction of teaching quality evaluation system. The construction of evaluation system of teaching quality is an important link of improving teaching quality and training benefit indispensable. Through the establishment of teaching quality evaluation standard system, scientific evaluation process, to improve the pertinence of the actual combat training. Innovative methods of actual teaching evaluation, qualitative analysis and quantitative analysis of a combination of methods, to determine a reasonable teaching system of quality evaluation factors and the weight, improve the scientific evaluation of the. Around the equipment repair ability of cadet actual combat environment formation of teaching quality evaluation, fully consider the combat team synergy, overall protection, integrated support capabilities, decompose various ability index, set up the evaluation index system of teaching quality in the capacity as the core, integrated balance evaluation, improve the authoritative evaluation.

\section{ACKNOWLEDGMENTS}

The work and results discussed in this paper was supported by Teaching Reform Foundation of Wuhan Mechanical Technology College.

\section{REFERENCES}

[1] Jia Ning.. Heads of agencies exercise organization and implementation. Education Teaching Forum, 2012, 4 (9), pp. 45-48.

[2] Lv Xiaoli, Bi Guangyuan, Xue Peng. Mobile Medical detachments comprehensive training to improve the level of countermeasures. Hospital Administration Journal of Chinese People's Liberation Armye, 2011, 18 (7): 14-16.

[3] Dai Hua, Xu Jin root. Based on a comprehensive exploration drill Teaching Information System. Continuing Education, 2013, 5, pp. 57-58. 